\title{
OPTIMASI TEMPERATUR YANG MEMPENGARUHI KEKERASAN PADA PEMBUATAN BALL MILL DENGAN CARA HOT ROLLING
}

\author{
Santhi Wilastari \\ Akademi Pelayaran Niaga Indonesia \\ Jl. Pawiyatan Luhur II No.17, Bendan Duwur, Banyumanik, Kota Semarang, Jawa Tengah 50235 \\ santhi.wilastari@yahoo.co.id
}

\begin{abstract}
Abstrak
Kata Kunci:

ball mill, temperatur quenching

Kekerasan merupakan salah satu sifat yang dibutuhkan oleh ball mill. Untuk mendapatkan sifat tersebut hingga saat ini masih dilakukan dengan cara trial and error sehingga sangatlah tidak efektif. Maka dari itu dilakukan suatu penelitian untuk mengetahui parameter - parameter yang mempengaruhi kekerasan ball mill dan level yang optimal. Ada tiga parameter yang diduga mempengaruhi kekerasan ball mill, yaitu temperatur raw material (Tm), temperatur awal proses quenching $(T q)$ dan temperatur akhir proses quenching $(T t)$.
\end{abstract}

\section{Abstract}

\section{Keywords:}

ball mill, temperatur

quenching

\begin{abstract}
Violence is one of the characteristics needed by the ball mill. To get this trait up to now is still done by trial and error so it is very ineffective. Therefore, a study was conducted to determine the parameters that affect the hardness of the ball mill and the optimal level. There are three parameters that are thought to affect ball mill hardness, namely the temperature of raw material (Tm), the initial temperature of the quenching process $(\mathrm{Tq})$ and the final temperature of the quenching process $(\mathrm{Tt})$.
\end{abstract}

\footnotetext{
Alamat korespondensi :

E-mail : santhi.wilastari@yahoo.co.id

ISSN : 2087-1627
} 


\section{Pendahuluan}

Logam hasil tambang biasanya masih dalam bentuk bijih-bijih logam yang di dalamnya banyak terdapat kotoran (impurities). Untuk meningkatkan kadar logam dilakukan pemurnian bijih logam dan hasilnya berupa konsentrat. Salah satu proses pemurnian yaitu dengan kominusi yang merupakan proses reduksi ukuran bijih mineral menjadi ukuran yang lebih kecil.

Kominusi dapat dibagi menjadi dua tahap yaitu crushing dan grinding. Tahap awalnya adalah crushing. Tahap akhir berupa grinding, yang dilakukan dengan menggunakan media grinding yang dapat berbentuk batang ataupun bola (ball mill). Ball mill harus memiliki kekerasan dan ketangguhan yang tinggi. Sifat ini dapat diperoleh dengan melakukan heat treatment pada ball mill. Banyak variabel yang mempengaruhi kekerasan dan ketangguhan selama proses heat treatment sehingga perlu ditentukan level yang optimal untuk mendapatkan kekerasan yang diinginkan

\section{Dasar Teori}

\subsection{Ball Mill}

Ball mill merupakan bola penggiling yang digunakan dalam proses reduksi ukuran biji mineral tambang menjadi ukuran yang lebih kecil yang disyaratkan mempunyai karakteristik keras (tahan aus) sekaligus tangguh (tidak mudah pecah) dan tahan korosi. Untuk mendapatkan bahan dengan persyaratan kekuatan yang harus dipenuhi oleh Ball Mill, maka bahan baku yang sesuai adalah logam yang mengandung Fe, yaitu besi dan baja. Besi dan baja memiliki sifat yang bervariasi, mulai.dari sifat yang paling lunak hingga paling keras serta memiliki sifat mampu bentuk yang baik dalam proses pengecoran sehingga berbagai macam bentuk coran dapat dibuat dengan pengecoran [1]..

Besi cor adalah logam paduan antara $\mathrm{Fe}-$ $\mathrm{C}$ yang mengandung 2\% $\mathrm{C}$ atau lebih [2]. Jumlah karbon yang tinggi membuat besi cor sangat rapuh. Dalam struktur mikro Besi Cor, karbon akan berubah menjadi Grafit dalam keadaan bebas dan Cementit dalam bentuk campuran. Cementit memiliki sifat sangat keras, rapuh dan mempunyai kekuatan tarik yang rendah [3].. Pembentukan Grafit sangat bergantung pada laju pendinginan coran dan komposisi kimia. Pada laju pendinginan yang cepat maka pembentukan Grafit akan terhambat sehingga struktur yang terbentuk adalah Cementit. Beberapa unsur yang dapat menghambat terbentuknya Grafit antara lain $\mathrm{Cr}, \mathrm{S}, \mathrm{Mo}, \mathrm{P}, \mathrm{Mn}$ dan $\mathrm{Mg}$ [4]..

Meskipun Besi Cor memiliki sifat yang rapuh dan keuletan yang rendah karena pengaruh sementit tetapi sifat-sifat Besi Cor dapat ditingkatkan dengan pengendalian pengecoran dan proses heat treament, sehingga dapat digunakan pada peralatan mesin dan industri. Kekuatan tarik besi cor antara $15-70 \mathrm{~kg} / \mathrm{mm} 2$ [5].. Keunggulan
Besi Cor terhadap baja terdapat pada kemampuan mesin yang baik, mudah dituang, kapasitas peredaman yang baik dan ketahanan aus yang tinggi [6]..

Pengelompokan Besi Cor berdasarkan kandungan Carbonnya terdiri dari Besi Cor Hypoeutektik (2\%-4,3\% C), Besi Cor Eutektik (4,3\% C) dan Besi Cor Hypereutektik (4,3\%-6,67\% C) [7].. Besi Cor menurut Van Flak [8]., dapat dibedakan menjadi 4 jenis, yaitu Besi Cor Kelabu (Gray Cast Iron), Besi Cor Putih (White Cast Iron), Besi Cor Nodular (Nodular Cast Iron) dan Besi Tuang mampu tempa (Malleable Cat Iron).

Besi Cor putih merupakan paduan Hypoeutektik dimana setelah penuangan dan membeku, Carbon akan bercampur dengan Besi membentuk Cementit [9]. Besi Cor Putih mengandung sejumlah besar Cementit sebagai jaringan kerja dalam Dendrit yang berkesinambungan menyebabkan Besi Cor Putih menjadi keras, tahan panas dan aus tetapi sangat rapuh dan sukar dikerjakan dengan mesin [10 dan 11]. Besi Cor Putih banyak digunakan pada pembuatan material yang tahan gesekan karena jumlah Karbida yang besar. Untuk mengurangi sifat rapuh, besi cor putih dapat di-anil sehingga Cementit akan terurai menjadi Besi dan Grafit [12].

Menurut Walton [13], karbida-karbida utama dalam struktur mikro Besi Tuang Putih memberikan kekerasan yang sangat tinggi yang diperlukan untuk memecahkan (crushing) dan menghancurkan (grinding) material lain tanpa terjadinya degradasi. Dukungan struktur matriks yang diatur oleh unsur paduan atau heat treatment menjaga keseimbangan antara ketahanannya terhadap keausan abrasi dan ketangguhan yang diperlukan untuk menanggung beban impak. Besi tuang putih paduan tinggi siap di cetak dalam berbagai bentuk yang diperlukan untuk memecahkan dan menghancurkan atau menangani material abrasive.

Menurut Granata [14], baja adalah logam paduan antara unsur Besi (Fe) dengan Karbon (C) dengan kadar karbon mencapai 2\%. Disamping kedua unsur dalam baja terdapat pula unsur-unsur dalam jumlah kecil, seperti Mangan (Mn), Silicon (Si), Fosfor (P), Belerang (S). Dapat juga dipadu dengan unsur-unsur paduan seperti Chromium (Cr), Nikel (Ni), Wolfram (W), Molibden (Mo) dan sebagainya, dan dapat divariasi menurut kebutuhan. Baja dapat dibentuk melalui pengecoran, pencanaian atau penempaan.

\subsection{Baja}

Dalam industri dikenal berbagai macam jenis baja. Jenis-jenis baja dapat dibedakan berdasarkan komposisi kimianya, proses pembuatan, penggunaannya atau berdasarkan salah satu sifat yang paling menonjol. Berdasarkan komposisi baja dapat dibagi, Baja Karbon dan Baja 
Paduan. Jenis baja paduan dibedakan menurut unsur paduannya. Baja mempunyai kekuatan tarik yang tinggi, antara 40-200 kg/mm2 [15]. Disamping itu Baja juga mempunyai sifat keras dan ulet. Dengan kombinasi sifat tersebut baja mempunyai kekuatan yang cukup tinggi. Sifat-sifat baja dapat diatur dengan cara pengaturan komposisi kimianya, terutama kadar Karbonnya [16]. Semakin tinggi kadar Karbon dalam Baja, semakin tinggi kekuatannya serta kekerasannya, sementara keuletannya berkurang. Disamping itu sifat-sifat baja dapat diatur melalui proses perlakuan panas (heat treatment).

Baja yang digunakan untuk bola adalah tipe AISI 5077. Baja ini merupakan baja paduan rendah $(<2,5 \%)$ dengan kandungan $\mathrm{Cr} 0,5 \%, \mathrm{C}$ $0,77 \%$, dan sisanya berupa $\mathrm{Mn}, \mathrm{Si}, \mathrm{Ni}, \mathrm{V}, \mathrm{Mo}$ dan P.

Diagram fase baja akan berubah dengan adanya unsur paduan. Unsur paduan yang berfungsi sebagai austenit stabilizer yaitu Ni dan Mn. Unsur ini cenderung untuk menurun kan temperatur eutektoid dan memperluas daerah austenit. Sedang unsur penstabil ferrit akan menggeser titik eutektoid ke kiri dan memperluas daerah ferrit. Hal ini harus diperhitungkan dalam proses laku panas terhadap baja paduan.

Unsur paduan juga akan menurunkan temperatur awal pembentukan martensit Ms dan akhir pembentukan martensit $\mathrm{Mf}$, ini berarti martensit mudah terbentuk atau akan menaikkan hardenability baja. Temperatur Ms dan Mf yang semakin rendah akan menyebabkan timbulnya retained austenit karena mungkin Mf sedemikian rendahnya sehingga pada temperatur kamar masih banyak terdapat austenit, sehingga kekerasan maksimum tidak tercapai.

\subsection{Quenching (hardening)}

Hardening merupakan salah satu laku panas dalam kondisi non equilibrium. Proses laku panas tersebut bertujuan untuk mengubah struktur mikro logam menjadi martensit. Sedangkan struktur mikro dan kadar karbon merupakan faktor yang berpengaruh terhadap kekerasan baja.

Quenching dilakukan dengan memanaskan baja hingga temperatur austenit dan ditahan beberapa saat pada temperatur tersebut, kemudian didinginkan dengan cepat. Kekerasan pada proses quenching dipengaruhi oleh beberapa faktor: temperatur austenitising, homogenitas austenit, laju pendinginan, kondisi permukaan dan ukuran benda kerja serta hardenability baja.

\subsection{Hot Rolling}

Pada proses hot rolling akan membentuk suatu material batang menjadi bola dengan cara memberi tekanan kepada benda kerja sehingga material berada didaerah pembentukannya berubah bentuk.

\section{Pembahasan}

Temperatur awal proses quenching memberikan pengaruh paling besar terhadap kekerasan ball mill. Hal ini karena martensit hanya terbentuk pada fase austenit yang didinginkan dengan sangat cepat. Logam akan bertransformasi allotropik dari ferrit menjadi austenit pada temperatur kritis.

Dengan semakin meningkatnya temperatur maka ferrit yang berubah menjadi austenit akan semakin banyak, ferrit akan habis dan menjadi austenit semuanya. Semakin tinggi temperatur awal quenching, austenit yang terbentuk semakin banyak dan mencapai maksimum. Austenit yang semakin banyak akan menghasilkan martensit yang semakin banyak pula pada pendinginan yang cepat. Hal ini akan mengakibatkan kekerasan akan meningkat pula.

Temperatur akhir proses quenching juga memberikan pengaruh terhadap kekerasan ball mill. Hal ini dikarenakan pada proses pendinginan yang cepat, martensit akan terbentuk jika laju pendinginan melebihi laju pendinginan kritis. Seiring dengan turunnya temperatur pada pendinginan yang cepat, austenit akan bertransformasi menjadi martensit ketika melewati garis Ms. Semakin rendah temperatur pendinginan maka austensit yang terbentuk akan semakin banyak sehingga kekerasan yang diperoleh akan semakin tinggi.

Interaksi antara temperatur awal dan temperatur akhir proses quenching juga mempengaruhi kekerasan pada ball mill. Lama proses pencelupan pada proses quenching mempengaruhi kekerasan. Semakin lama waktu pencelupan, berarti memberi waktu yang cukup lama bagi austenit untuk bertransformasi menjadi martensit. Pada bagian tengah ball mill akan mengalami laju pendinginan yang lambat dibanding di bagian permukaannya, sehingga akan menyebabkan waktu yang diperlukan untuk bertransformasi ke martensit menjadi lebih lama.

Temperatur raw material (Tm) tidak memberi pengaruh terhadap kekerasan bal milll. Hal ini dikarenakan terbentuknya martensit karena adanya proses pendinginan yang cepat. Sedangkan temperatur awal material tidak berpengaruh karena material tersebut tidak mengalami proses pendinginan yang cepat.

Interaksi antara temperatur raw material dan temperatur awal proses quenching tidak berpengaruh terhadap kekerasan ball mill. Hal ini disebabkan proses pemanasan material hingga material yang terbentuk menjadi bola tidak mengalami proses pendinginan yang cepat melainkan bola yang terbentuk dibawa terlebih dahulu ke wadah pencelupan. Selama bola dibawa ke wadah pencelupan temperatur material masih tetap tinggi. 
Interaksi antara temperatur raw material dan temperatur akhir proses quenching tidak berpengaruh terhadap kekerasan ball mill. Hal ini disebabkan karena temperatur raw material tidak secara langsung mempengaruhi temperatur akhir proses quenching.

Interaksi antara temperatur raw material, temperatur awal dan temperatur akhir proses quenching tidak berpengaruh terhadap kekerasan bal milll. Hal ini disebabkan karena temperatur raw material dan temperatur awal proses quenching keduanya tidak mengalami perubahan yang berarti sehingga tidak menyebabkan terjadinya transformasi allotropik.

\section{Kesimpulan}

Dari pembahasan mengenai pengaruh temperatur terhadap kekerasan ball mill, maka dapat disimpulkan bahwa kekerasan ball mill dipengaruhi oleh temperatur awal dan temperatur akhir proses quenching serta interaksi antara keduanya. Temperatur awal proses quenching sebaiknya diatur pada $905 \pm 10^{\circ} \mathrm{C}$ dan temperatur akhir proses quenching pada $133 \pm 3^{\circ} \mathrm{C}$. Sedangkan temperatur awal material pada $1100 \pm$ $10^{\circ} \mathrm{C}$.

\section{DAFTAR PUSTAKA}

1. Tata Surdia \& Saito, S., Pengetahuan Bahan Teknik, Cetakan Kelima, PT. Pradnya Paramita, Jakarta, 2000

2. Amstead, B.H., Teknologi Mekanik, Jilid Kesatu, Edisi Ketujuh, Erlangga, Jakarta, 1985.

3. Shackelford, J.F., Introduction to Material Science for Engineers, 3th ed., McMillan Publishing Company, New York, 1992.

4. Smith, W. F., Structure and Properties of Engineering Alloys, 2nd ed., McGraw-Hill, Inc., New York, 1993.

5. Smith, W. F., Principles of Materials Science and Engineering, McGraw-Hill Publishing Company, New York, 1990.

6. Smallman, R. E., Metalurgi Fisik Modern, Terj. Sriati Djaprie, Edisi Keempat, PT. Gramedia Pustaka Utama, Jakarta, 1985.

7. Lakhtin, Y, Enginering Physical Metalurgy, MR. Publisher, Moscow, 1987.

8. Van-Vlack, L.H., Ilmu dan Teknologi Bahan, Edisi Kelima, Erlangga, Jakarta, 1983.

9. Avner, B.H., Introduction to Physical Metallurgy, 3rd ed., McGraw- Hill Int., London, 1987.

10. Budinski, K. G., Engineering Materials Properties and Selection, 3rd ed., Prentice-Hall, Inc., New Jersey, 1989.

11. Callister, Jr. W. D., Materials Science and Engineering an Introduction, 3rd ed., John Wiley \& Sons, Inc., New York, 1997.
12. Davis, J.R., Surface Engineering of Carbon and Alloy Steels, dalam Metals Handbook, 9th ed., vol.6, American Society for Metals, Metals Park, Ohio, 1996.

13. Walton, F. C., 1981, Iron Casting Handbook, 2ndedition, Iron Casting Society, Inc., Florida.

14. Granata, R.D. dan Moore, P.G., Surface Modification,dalam Metals Handbook, 9th ed., vol.6, American Society for Metals, Metals Park, Ohio, 1986.

15. Polukhin, A. T., Grinberg, B., Kantenik, S., Zhadan, V. and Vasilxev, D., Metal Process Engineering, Peace Publisers, Moscow, 1977.

16. Dieter, G. E., Mechanical Metallurgy, 3rd ed., McGraw-Hill, New York, 1986. 